\title{
A novel cromakalim analogue induces cell cycle arrest and apoptosis in human cervical carcinoma HeLa cells through the caspase- and mitochondria-dependent pathway
}

\author{
XIN ZHANG ${ }^{1,2}$, JING ZHAO $^{1,2}$, SAEROMI KANG ${ }^{2}$, MYEONGJIN YI $^{2}$, \\ SONG YOU ${ }^{1}$, DONG-SOO SHIN ${ }^{3}$ and DONG-KYOO KIM ${ }^{2}$ \\ ${ }^{1}$ School of Life Science and Biopharmaceutics, Shenyang Pharmaceutical University, Shenyang 110016, P.R. China; \\ ${ }^{2}$ Department of Biomedicinal Chemistry and Institute of Basic Science, Inje University, 607 Aubang-dong, \\ Gimhae 621-749; ${ }^{3}$ Department of Chemistry, Changwon National University, Changwon, Republic of Korea
}

Received June 9, 2011; Accepted July 14, 2011

DOI: $10.3892 /$ ijo.2011.1153

\begin{abstract}
In the present study, a series of seven synthetic cromakalim analogues were prepared and evaluated for cytotoxic effect on human cervical carcinoma HeLa cells using WST-8 assay. A preliminary screening of these cromakalim analogues showed that 1-[(3S,4R)-4-(2-ethoxy-4-methyl-1H-pyrrol-1-yl)-3-hydroxy2,2-dimethylchroman-6-yl-3-phenylurea (compound 6) had the highest cytotoxic effect $\left(\mathrm{IC}_{50}\right.$ of $\left.138 \mu \mathrm{M}\right)$ and significantly inhibited HeLa cell proliferation after $36 \mathrm{~h}$. In an effort to understand the cytotoxic mechanism of compound 6 , we examined its effect on apoptosis and cell cycle distribution. Our results showed that compound 6 induced marked changes in apoptotic morphology and significantly increased early apoptosis of HeLa cells after $48 \mathrm{~h}$ by using Annexin V-FITC/PI dual staining assay. This apoptotic induction was associated with an increase in Bax expression, a decrease in Bcl-2 expression, release of cytochrome $\mathrm{c}$ and subsequent activation of caspase- 9 and -3 , which indicated that compound 6 induced apoptosis via caspaseand mitochondria-dependent pathway. By DNA content analysis and $\left[{ }^{3} \mathrm{H}\right]$ thymidine incorporation assay, compound 6 was found to induce an increase in the number of cells in G1 phase, accompanied by a decrease in the $\mathrm{S}$ phase to prevent DNA synthesis after $24 \mathrm{~h}$ of treatment. In addition, compound 6 caused significant DNA damage, as detected by the alkaline comet assay. Taken together, the data demonstrate that compound 6 induces apoptosis in HeLa cells through caspase- and mitochondriadependent pathway and this apoptotic effect is associated with cell cycle arrest and DNA damage. These findings provide further understanding of the molecular mechanisms of compound 6 in cervical cancer.
\end{abstract}

Correspondence to: Dr Dong-Kyoo Kim, Department of Biomedicinal Chemistry and Institute of Basic Science, Inje University, 607 Aubang-dong, Gimhae 621-749, Republic of Korea

E-mail: chemkdg@inje.ac.kr

Key words: cromakalim analogue, apoptosis, cell cycle arrest, caspase, mitochondria

\section{Introduction}

Cromakalim, a potassium channel opener, presents antitumor potential against human neuroblastoma and human astrocytoma cell lines. The suggested mechanism of this antitumor effect is the activation of ATP-sensitive potassium channels leading to the inhibition of the intracellular $\mathrm{Ca}^{2+}$ signaling mechanism (1). Although a series of 4,6-disubstituted 2,2-dimethylchromans structurally related to cromakalim have been synthesized and reported to possess several pharmacological effects including potassium channel activating, antihypertensive and anti-ischemic properties (2-5), no attempt has been made to evaluate the cytotoxicity of cromakalim analogues, and the exact pathways involved in their cytotoxic effect are not completely elucidated in the case of human cervical carcinoma HeLa cells.

Many reports demonstrated that DNA damage was induced in cancer cells by exposure to chemotherapy drugs $(6,7)$, and that DNA-strand breakage may be one reason for DNA lesions, which can be sensitively detected by the single-cell gel electrophoresis (comet) assay in anticancer studies (8). Detection of genomic lesions activates the DNA damage response, which determines cell fate according to the extent of damage. If the damage is manageable, the DNA damage response arrests the cell cycle progression and induces DNA repair to prevent replication of damaged DNA. If the damage is beyond repair, cells undergo apoptosis (9).

Apoptosis has been characterized as a fundamental cellular activity which maintains the physiological balance of the organism. It is involved in immune defense mechanisms that play a necessary role in protecting against carcinogenesis by eliminating damaged or abnormal excess cells which have proliferated owing to the induction of various chemical agents $(10,11)$. Morphologically, apoptosis is characterized by shrinkage of the cell, dramatic reorganization of the nucleus, active membrane blebbing and, ultimately, fragmentation of the cell into membrane-enclosed vesicles (apoptotic bodies) (12). In the early stage of apoptosis, the membrane phospholipid phosphatidylserine (PS) is translocated from the inner to the outer leaflet. Annexin V has a high affinity for PS, which identifies apoptosis at this earlier stage. 
A significant body of literature has accumulated demonstrating the importance of mitochondria as critical regulators of the intrinsic apoptotic pathway in response to DNA damage. Upon apoptotic stimulation, several important events occur at the mitochondria, including the release of cytochrome $\mathrm{c}$ from the mitochondria into the cytoplasm $(13,14)$. Cytochrome $c$ binds to the apoptotic protease activating factor 1 (Apaf-1), which then recruits procaspase- 9 to form an apoptosome. This complex activates caspase- 9 which in turn cleaves and activates effector procaspases to active effector caspases, such as caspase-3. These effector caspases cleave a number of substrates resulting in morphological and biochemical changes of apoptosis $(15,16)$. The activation of mitochondria and release of intermembrane contents of mitochondria are under regulatory control of a number of Bcl-2 family proteins (17-19). Some of these members, including $\mathrm{Bcl}-2$, prevent the release of cytochrome c and therefore serve as anti-apoptotic proteins, whereas others, such as Bax, promote the release of cytochrome $\mathrm{c}$ and serve as pro-apoptotic molecules.

In this study, we examined the cytotoxicity of seven cromakalim analogues (Fig. 1) against HeLa cells. In addition, the apoptosis-inducing effect of 1-[(3S,4R)-4-(2-ethoxy-4methyl-1H-pyrrol-1-yl)-3-hydroxy-2,2-dimethylchroman-6-yl]3 -phenylurea (compound 6) and its underlying mechanism were investigated.

\section{Materials and methods}

Chemicals. The propidium iodide (PI)/RNase staining buffer and Annexin-FITC kit for apoptosis were from BD Biosciences Pharmingen (San Diego, CA, USA). Dimethyl sulfoxide (DMSO) and phosphate-buffered saline (PBS, pH 7.4) were purchased from Sigma-Aldrich Chemical Co. (St. Louis, MO, USA). Eagle's minimum essential medium (EMEM), fetal bovine serum (FBS), penicillin-streptomycin and trypsinEDTA were obtained from Hyclone Laboratories, Inc. (Logan, UT, USA). Cell Counting Kit-8 (CCK-8) was purchased from Dojindo Molecular Technologies, Inc. (Osaka, Japan). All other chemicals were of analytical reagent grade.

Preparation of cromakalim analogues. Seven cromakalim analogues were synthesized from the laboratory of Dr D.S. Shin and their structures were determined by means of spectral analyses (HPLC, MS, ${ }^{1} \mathrm{H}$ NMR and ${ }^{13} \mathrm{C}$ NMR). Compound 6 , 1-[(3S,4R)-4-(2-ethoxy-4-methyl-1H-pyrrol-1-yl)-3-hydroxy-2, 2-dimethylchroman-6-yl]-3-phenylurea, appears as a white solid with the melting point $201-202^{\circ} \mathrm{C} ;[\alpha]_{\mathrm{D}}^{20}+18.8$ (c 1.0, $\mathrm{MeOH})$. Compound 6 was identified according to the spectrometric data: IR $\left(\mathrm{KBr}, \mathrm{cm}^{-1}\right)$ : 3327, 3140, 3065, 2981, 2935 , 1696, 1605, 1551, 1498, 1449, 1396, 1304, 1220, 1137, 1087, 1034, 924, 821, 753, 696; ${ }^{1} \mathrm{H}$ NMR (400 MHz, $\left.\mathrm{CDCl}_{3}\right) \delta 1.20$ (s, 3H), 1.28 (s, 3H), 1.40 (t, J=6.8 Hz, 3H), $2.12(\mathrm{~s}, 3 \mathrm{H}), 4.14-$ $4.18(\mathrm{~m}, 2 \mathrm{H}), 4.21(\mathrm{~d}, \mathrm{~J}=9.6 \mathrm{~Hz}, 1 \mathrm{H}), 5.16(\mathrm{~d}, \mathrm{~J}=9.6 \mathrm{~Hz}, 1 \mathrm{H})$, $5.40(\mathrm{~s}, 1 \mathrm{H}), 6.75(\mathrm{~d}, \mathrm{~J}=8.8 \mathrm{~Hz}, 1 \mathrm{H}), 6.99-7(\mathrm{~m}, 1 \mathrm{H}), 7.22-7.41$ $(\mathrm{m}, 5 \mathrm{H}), 7.65(\mathrm{~s}, 1 \mathrm{H}) ;{ }^{13} \mathrm{C}$ NMR $\left(100 \mathrm{MHz}, \mathrm{CDCl}_{3}\right)$ 14.14, 14.53, 17.97, 26.26, 68.03, 72.75, 78.12, 85.26, 118.09, 118.16, $19.44,120.38,122.62,123.26,128.78,132.06,138.99,149.04$, 149.18, 153.30, 157.33; MS (EI) m/z: 317 ( $\left.\mathrm{M}^{+}-119,100 \%\right), 246$ (44), 134 (28), 217 (16), 191(15), 176 (31), 150 (28). Stock solutions of the cromakalim analogues were prepared in DMSO

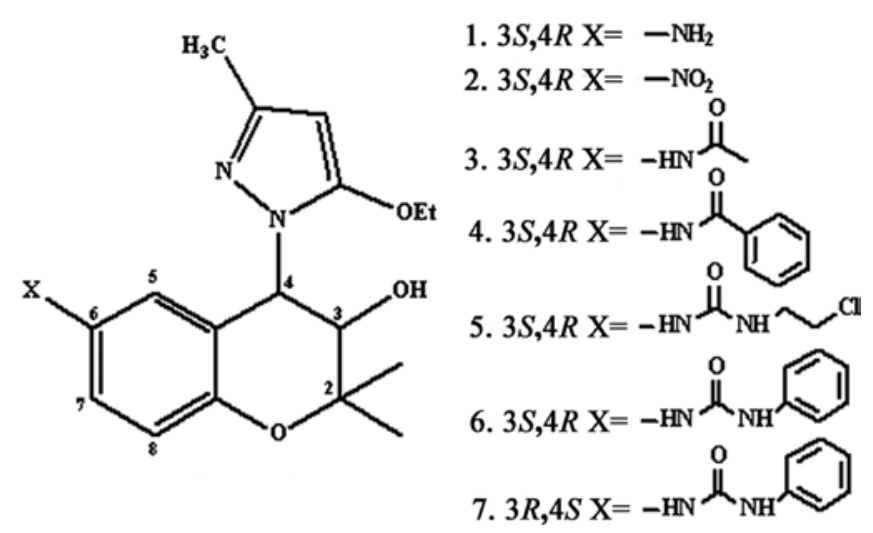

Figure 1. Chemical structure of seven cromakalim analogues.

and kept at $4^{\circ} \mathrm{C}$. Further dilutions were made immediately prior to each experiment.

Cell lines. HeLa cells obtained from American Type Culture Collection (ATCC) were cultured in EMEM medium supplemented with $10 \% \mathrm{FBS}$ at $37^{\circ} \mathrm{C}\left(5 \% \mathrm{CO}_{2}\right)$ in a humidified atmosphere.

Cell viability and proliferation assay. The effect of cromakalim analogues on cell viability was investigated on HeLa cells according to the method of Tominaga et al (20). Cells were plated at $5 \times 10^{3}$ cells into each well of a 96-well microplate. After $24 \mathrm{~h}$, media were substituted by fresh media containing cromakalim analogues at various concentrations (75, 150 and $300 \mu \mathrm{M}$ ). The plate was incubated further for 48 h. CCK-8 reagent ( $10 \mu \mathrm{l})$ was then added to each well followed by $2 \mathrm{~h}$ incubation. The cell viability was assessed by WST-8 [2-(2-methoxy-4-nitrophenyl)-3-(4-nitrophenyl)-5-(2,4disulfophenyl)- ${ }^{2} \mathrm{H}$-tetrazolium], an indicator that is reduced by dehydrogenases in cells to give an orange colored product (formazan), which is soluble in cell culture medium. The optical density for living cells was read at $450 \mathrm{~nm}$ in a multimicroplate reader (synergy HT, BIO-TEK ${ }^{\circledR}$ ). Wells containing cells and an appropriate volume of the vehicle (DMSO) served as the control. Wells containing only culture medium and CCK- 8 reagent served as the blank. Percentage cytotoxicity of BSM was calculated according to the following equation:

$$
\% \text { cytotoxicity }=\left[\left(A_{c}-A\right) /\left(A_{c}-A_{b}\right)\right] \times 100
$$

where $A_{c}, A_{b}$ and $A$ represent the mean optical density of the vehicle control, blank and treated groups, respectively. In order to determine the effect of compound 6 on cell proliferation, cells were seeded at $5 \times 10^{3} / \mathrm{ml}$ media in 96 -well plates and treated with or without compound $6(150 \mu \mathrm{M})$ for various times. Each experiment was repeated at least three times.

Measurement of apoptotic cell morphology. HeLa cells were distributed $\left(1 \times 10^{5}\right.$ cells/well) into a 24 -well plate and allowed to adhere overnight. The cells were treated with compound 6 $(150 \mu \mathrm{M})$ for 24 and $48 \mathrm{~h}$. Non-treated wells received an equivalent volume of DMSO $(<0.1 \%)$ serving as the control. Optic 


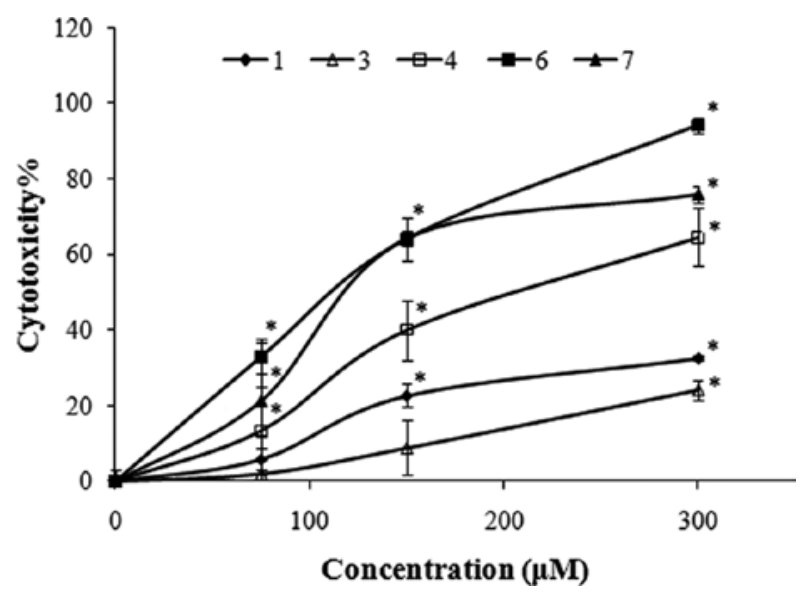

Figure 2. Cytotoxicity of cromakalim analogues against HeLa cells. HeLa cells were treated with cromakalim analogues at various concentrations $(0,75,150$ and $300 \mu \mathrm{M}$ ) for $48 \mathrm{~h}$. Results are the mean $\pm \mathrm{SD}, \mathrm{n}=3$. ${ }^{*} \mathrm{P}<0.05$, means significantly differ from the control at the same level.

phase-contrast photographs were taken with a Nikon ${ }^{\mathrm{TM}}$ Phase Contrast-2, ELWD 0.3 inverted microscope.

Annexin V-FITC/PI apoptotic analysis. The cells $\left(3 \times 10^{5}\right.$ cells in $60 \mathrm{~mm}$ dish) treated with or without compound 6 were collected by trypsinization and washed with ice-cold PBS via centrifugation. Then, $1 \times 10^{5}$ cells were resuspended in $100 \mu \mathrm{l}$ of binding buffer and stained with $5 \mu \mathrm{l}$ of Annexin V-FITC and $10 \mu \mathrm{l}$ of PI $(50 \mu \mathrm{g} / \mathrm{ml})$ for $15 \mathrm{~min}$ at room temperature in the dark. Analysis was performed by FACSCalibur flow cytometer (Becton-Dickinson, San Jose, CA) with 10,000 events each time. The data were analyzed by the CellQuest software (Becton-Dickinson Instruments, Franklin Lakes, NJ).

Protein extraction and Western blot analysis. After cells were treated with or without compound 6 , total cell lysates and cytosolic fractions were prepared as previously described (21). Protein contents of the lysates were determined by the Bradford protein assay (Bio-Rad, Hercules, CA, USA). Proteins $(25 \mu \mathrm{g})$ were resolved by sodium dodecyl sulfate polyacrylamide gel electrophoresis (SDS-PAGE) and transferred onto nitrocellulose membranes (Schleicher \& Schuell, USA) by Western blotting (22). The results were quantified using Image J 1.43 (C) (National Institutes of Health, Bethesda, MD, USA). The following primary polyclonal antibodies were used: Bcl-2, caspase-9, $\beta$-actin (1:1000; Cell Signaling Technology, Danvers, USA), cytochrome c, caspase-3 (1:200; Santa Cruz Biotechnology, Santa Cruz, USA) and Bax (1:1000; BD PharMingen, San Diego, CA).

DNA content analysis. The cells ( $3 \times 10^{5}$ cells in $60 \mathrm{~mm}$ dish) treated with or without compound 6 were collected by trypsinization and washed with ice-cold PBS via centrifugation. The cells were suspended in PBS and fixed with $70 \%$ ethanol (v/v). Samples were then washed with ice-cold PBS and stained with $\mathrm{PI} / \mathrm{RNase}$ staining buffer for $15 \mathrm{~min}$ at room temperature. The cells in different phases of the cell cycle were analyzed using a FACScan flow cytometer analysis system, and 20,000 events were analyzed for each sample. The percentage of cells in the different phases of cell cycle was determined using Modfit software (Becton-Dickinson Instruments).

$\left[{ }^{3} \mathrm{H}\right]$ thymidine incorporation assay. The $\left[{ }^{3} \mathrm{H}\right] \mathrm{dTTP}$ incorporation assay was performed as previously described (23). Briefly, HeLa cells were applied to 12 -well plates in a growth medium (EMEM + 10\% FBS). After the cells had grown to 70-80\% confluence, they were rendered quiescent by incubation for $24 \mathrm{~h}$ in EMEM containing 2\% FBS. Compound $6(150 \mu \mathrm{M})$ (or DMSO) in EMEM supplemented with 10\% FBS and was added to the cells and the cultures were allowed to incubate for 21 and $45 \mathrm{~h}$. $\left[{ }^{3} \mathrm{H}\right] \mathrm{dTTP}$ was added at $1 \mu \mathrm{Ci} / \mathrm{ml}(1 \mu \mathrm{Ci}=$ $37 \mathrm{kBq})$ and incubated further for $3 \mathrm{~h}$. Incorporated $\left[{ }^{3} \mathrm{H}\right] \mathrm{dTTP}$ was extracted in cell lysis buffer and measured in a liquid scintillation analyzer (Tri-Carb 2910TR, Perkin-Elmer Inc., USA).

Single-cell gel electrophoresis. To examine the DNA damage in the single-cell suspensions, we performed an alkaline single-cell gel electrophoresis (comet assay). The comet assay was carried out as previously described (24). The data were analyzed using the Comet 5.5 software. Olive tail moment (OTM) approved by Olive was used to evaluate DNA damage. OTM, expressed in arbitrary units, is calculated by multiplying the percent of DNA (fluorescence) in the tail by the length of the tail in $\mu \mathrm{m}(25,26)$. The tail length is measured between the edge of the Comet head and the end of its tail. A major advantage of using the OTM as an index of DNA damage is that the amount of damaged DNA and the distance of migration of the genetic material in the tail are represented by a single number (27).

Statistical analysis. Data were collected and expressed as the mean \pm standard deviation (SD) of three independent experiments. Statistical analysis was performed by one-way analysis of variance (ANOVA), and differences from the respective controls for each experimental test condition were determined using $t$-tests. The criterion for significance was set at $\mathrm{P}<0.05$. The 19th version of SPSS (SPSS, Chicago, IL, USA) and Microsoft Excel 2007 (Roselle, IL, USA) were used for the statistical and graphical evaluations.

\section{Results}

Cytotoxic effect of cromakalim analogues. Initially, the cytotoxicity of different concentrations of the cromakalim analogues against HeLa cells was determined by WST-8 assay. After incubation of HeLa cells with increasing concentrations $(75,150$ and $300 \mu \mathrm{M})$ of the cromakalim analogues for $48 \mathrm{~h}$, only compounds 4, 6 and 7 showed significant cytotoxicity in a concentration-dependent manner, when compared with the control (Fig. 2). $\mathrm{IC}_{50}$ (the median inhibitory concentration) values were 224,138 and $174 \mu \mathrm{M}$, respectively (Table I). No expressive effect was observed for any of the other cromakalim analogues. Compound 6 was chosen for further study because it caused the most significant cell death at concentrations tested.

For treatment of HeLa cells with $150 \mu \mathrm{M}$ of compound 6 for $0,12,24,36,48$ and $60 \mathrm{~h}$, the proliferation of compound 6 -treated cells gradually increased to $36 \mathrm{~h}$ and began to decrease at $48 \mathrm{~h}$, whereas the untreated cells maintained an exponential 


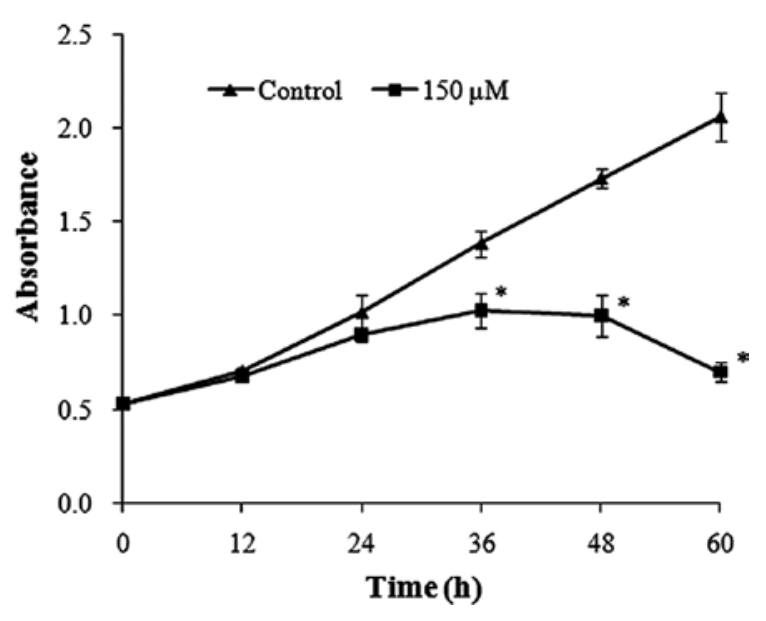

Figure 3. Effect of compound 6 on the proliferation of HeLa cells. HeLa cells were treated with either vehicle alone or $150 \mu \mathrm{M}$ of compound 6 for $0,12,24$, 36,48 and $60 \mathrm{~h}$. Results are the mean $\pm \mathrm{SD}, \mathrm{n}=3$. ${ }^{*} \mathrm{P}<0.05$, means significantly differ from the control at the same level.

proliferation state (Fig. 3). A significant difference in the absorbance from the control was observed at $36 \mathrm{~h}$, showing that compound 6 inhibited HeLa cell proliferation after $36 \mathrm{~h}$ incubation.

Compound 6 induces apoptosis in HeLa cells. To evaluate whether compound 6 induces cell death via apoptosis or necrosis pathway, both morphology observation and Annexin V-FITC/PI double staining assay were performed to assess compound 6-induced apoptosis in HeLa cells. Changes in the
Table I. $\mathrm{IC}_{50}$ values of seven synthetic cromakalim analogues by WST- 8 assay in HeLa cells.

\begin{tabular}{lc}
\hline Cromakalim analogues & $\mathrm{IC}_{50}(\mu \mathrm{M})$ \\
\hline Compound 1 & $>300$ \\
Compound 2 & No effect \\
Compound 3 & $>300$ \\
Compound 4 & 224 \\
Compound 5 & No effect \\
Compound 6 & 138 \\
Compound 7 & 174 \\
\hline
\end{tabular}

cells treated with an $\mathrm{IC}_{50}$ concentration of compound 6 using light microscopy revealed morphological features of apoptosis. As shown in Fig. 4A and C, non-treated cells spread regularly in the culture plates and grew to near confluence. After a $24 \mathrm{~h}$ treatment with compound 6, some HeLa cells floated, but the majority of the attached cells kept a normal cellular shape (Fig. 4B). After 48 h, however, a significant proportion of the HeLa cells dislodged from their plates and most of the remaining attached cells showed typical morphological changes corresponding to apoptosis, which was characterized by cellular shrinkage and disruption (Fig. 4D).

To obtain further evidence for the induction of apoptosis by compound 6 , HeLa cells were treated with or without 150 $\mu \mathrm{M}$ of compound 6 for 24 and $48 \mathrm{~h}$ and then marked with Annexin V-FITC and PI, followed by analysis using flow cytometry. This double-staining method allows live non-
(A)

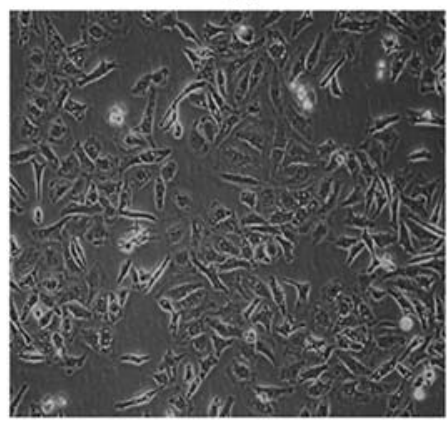

(C)

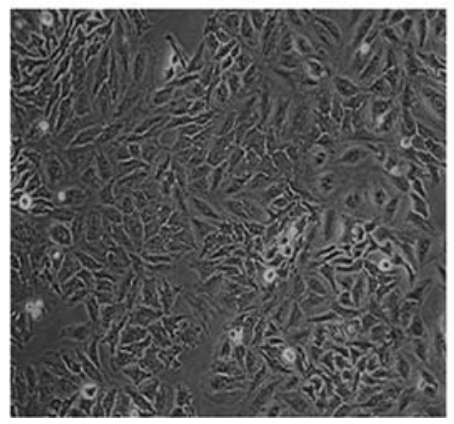

(B)

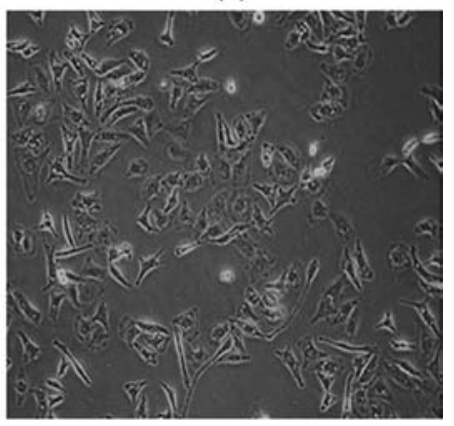

(D)

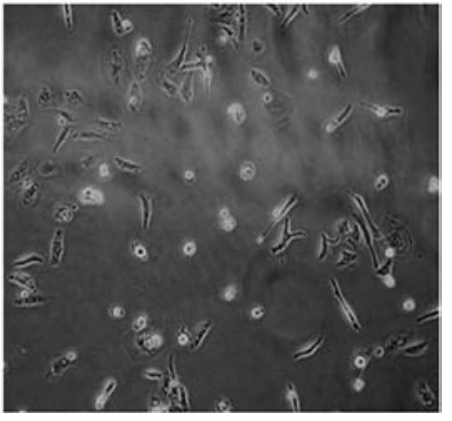

Figure 4. Morphological changes in HeLa cells. Exponentially growing cells were treated with either vehicle alone for 24 (A) and $48 \mathrm{~h}$ (C) or $150 \mu \mathrm{M}$ of compound 6 for 24 (B) and 48 h (D). Magnification, x160. 

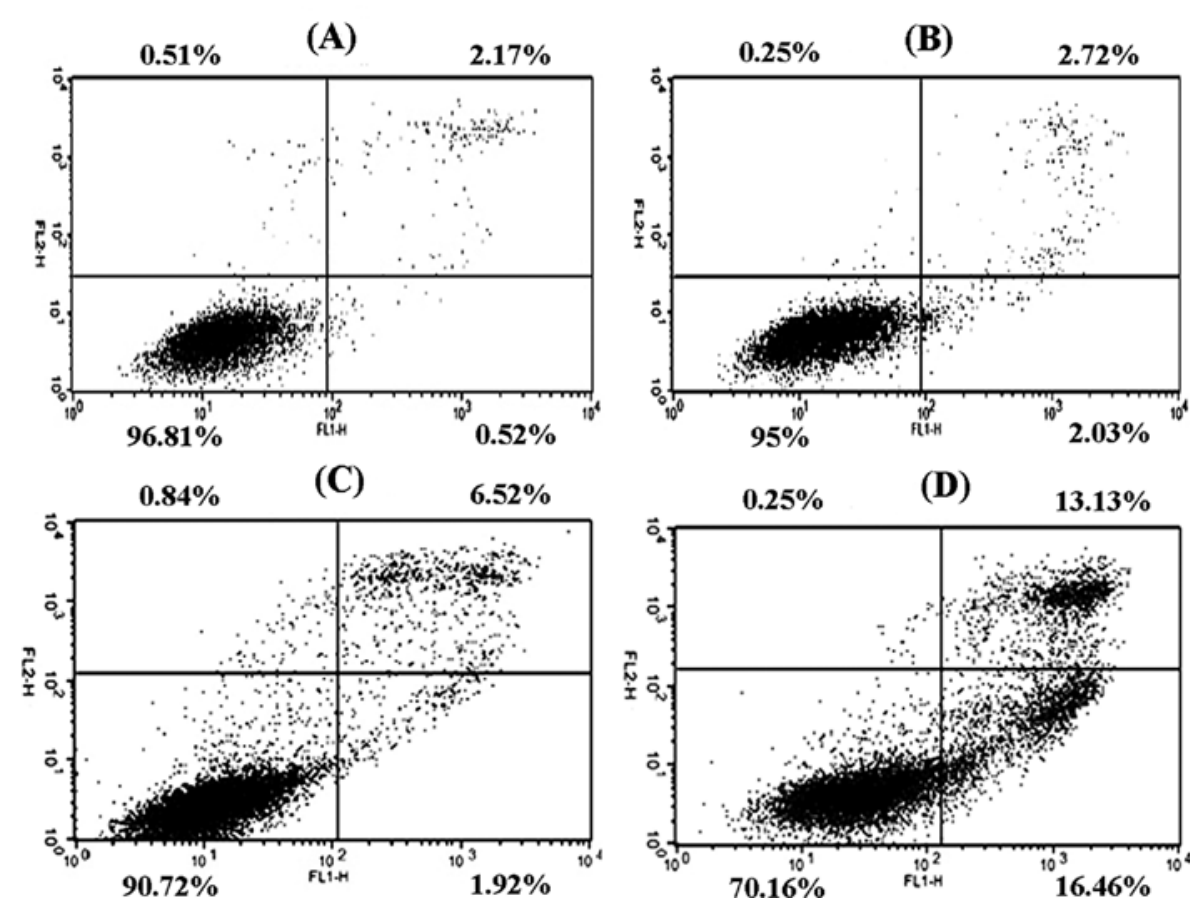

Figure 5. Measurement of apoptotic population induced by compound 6. HeLa cells were treated with either vehicle alone for 24 (A) and $48 \mathrm{~h}(\mathrm{C})$ or $150 \mu \mathrm{M}$ of compound 6 for 24 (B) and $48 \mathrm{~h}$ (D). All experiments were performed in duplicate and gave similar results.

apoptotic cells (Annexin $\left.\mathrm{V}^{\text {negative }} / \mathrm{PI}^{\text {negative }}\right)$ to be distinguished from early apoptotic cells (Annexin $\left.\mathrm{V}^{\text {positive }} / \mathrm{PI}^{\text {negative }}\right)$ and late apoptotic cells (Annexin $\mathrm{V}^{\text {positive }} / \mathrm{PI}^{\text {positive }}$ ) (28-29). As illustrated in Fig. 5A, 96.81\% of vehicle alone-treated HeLa cells were viable for $24 \mathrm{~h}$, and $0.52 \%$ were early apoptotic cells. There was no major change under compound 6-treatment in cell distribution compared with control cells at $24 \mathrm{~h}$ (Fig. 5B). However, a $48 \mathrm{~h}$ treatment with compound 6 significantly increased the percentage of early apoptotic cells from 1.9 to $16.5 \%$ (Fig. $5 \mathrm{C}$ and D). In addition, the percentage of late apoptotic cells (or necrotic cells) was also increased by treatment of compound 6 . By using both the apoptosis detection methods, we determined that compound 6 treatment significantly enhanced apoptosis over control values after $48 \mathrm{~h}$.

Compound 6 regulates Bax and Bcl-2, induces cytochrome $c$ release and causes activation of caspases. The Bcl-2 family proteins Bax and Bcl-2 molecules play important roles in initiating mitochondrial death cascade (19). To investigate the underlying mechanism of apoptosis induced by compound 6 , the expressions of Bax and Bcl-2 were measured by Western blot analysis. The expression level of the pro-apoptotic protein Bax was significantly upregulated in a dose-dependent manner, whereas the expression level of the anti-apoptotic protein Bcl-2 was slightly downregulated (Fig. 6A and B). Correspondingly, a dramatic increase in the $\mathrm{Bax} / \mathrm{Bcl}-2$ ratio was shown in Fig. 6C. Following the changes of Bcl-2 family members, cytochrome $\mathrm{c}$ is released from the mitochondria into the cytoplasm, which in turn activates a downstream caspase program (15). As shown in Fig. 6A and B, the protein expression of cytosolic cytochrome c significantly increased in a dose-dependent manner, which indicated that the mito- chondrial dysfunction was involved in the apoptosis induced by compound 6 in HeLa cells. Furthermore, decreases in both procaspase- 9 and -3 expression levels were observed, demonstrating the activation of caspase cascade. These results suggest that compound 6 induced apoptosis in HeLa cells via caspase- and mitochondria-dependent pathway.

Compound 6 causes G1 cell cycle arrest, associated with inhibition of DNA synthesis. The cell growth and inhibition are both tightly mediated through cell cycle control (30), and the dysregulation of cell cycle progression has been implicated in the initiation of apoptosis $(31,32)$. In order to examine further the actions of compound 6 on cell cycle, the cell cycle distribution of HeLa cells treated by compound $6(150 \mu \mathrm{M})$ was studied by DNA content analysis. As illustrated in Fig. $7 \mathrm{~A}$ and $\mathrm{B}$, after a $24 \mathrm{~h}$ treatment, compound 6 induced a significant accumulation of cells in the G1 phase in HeLa cells $(68-78 \%)$. Concomitantly, there was a significant decrease of cells in the S phase from a control value of $15-23 \%$, while no effect on the cell number in the G2/M phase. The level of G1 arrest induced by compound 6 in HeLa cells did not show a time-dependent manner until 48 h (Fig. 7). Moreover, Fig. 8 showed a significant reduction of the $\left[{ }^{3} \mathrm{H}\right] \mathrm{dTTP}$ incorporation in HeLa cells during S-phase of cell cycle. From proliferation assay, it was found that there was no significant difference in cell numbers between control and compound 6-treated HeLa cells at $24 \mathrm{~h}$ (Fig. 3), suggesting that there was an inhibitory effect of compound 6 on the process of DNA synthesis. However, the cell number of $48 \mathrm{~h}$ was slightly higher than that of $24 \mathrm{~h}$, resulting in a moderate increase in the $\left[{ }^{3} \mathrm{H}\right] \mathrm{dTTP}$ incorporation at $48 \mathrm{~h}$ compared with $24 \mathrm{~h}$. The data reveal that the actions of compound 6 blocked HeLa cells in the 
(A)

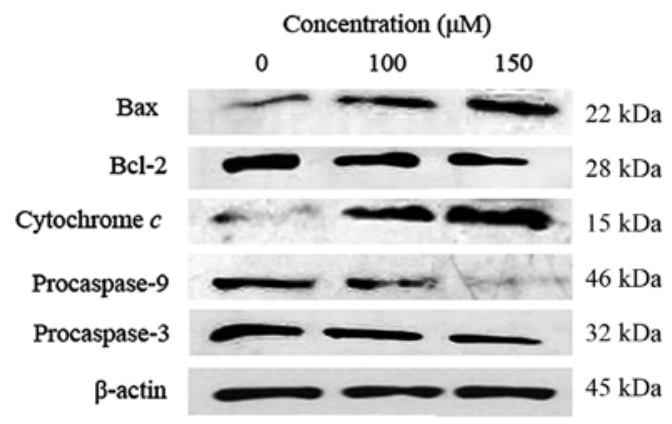

(B)
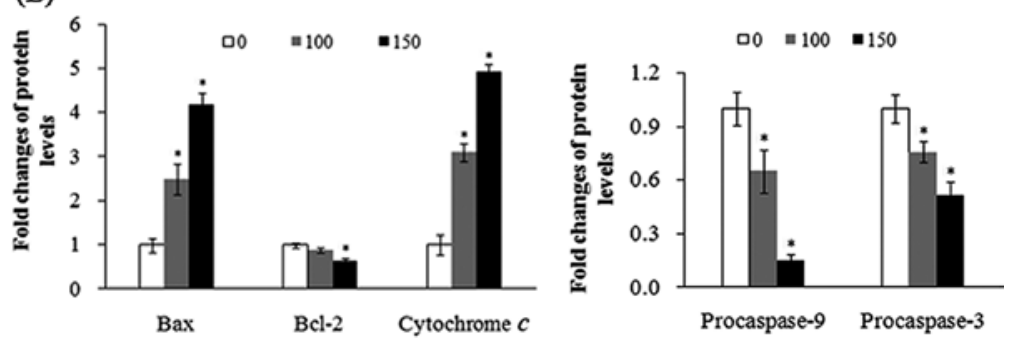

(C)

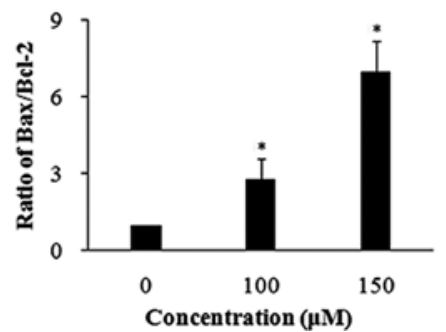

Figure 6. Involvement of protein activation in compound 6-induced apoptosis. (A) Protein expression of Bax, Bcl-2, cytochrome c, procaspase-9 and -3. (B) Fold changes in Bax, Bcl-2, cytochrome c, procaspase-9 and -3 levels. (C) Ratio of Bax/Bcl-2. Results are the mean $\pm \mathrm{SD}, \mathrm{n}=3$. " $\mathrm{P}<0.05$, means significantly differ from the control at the same level.

(A)

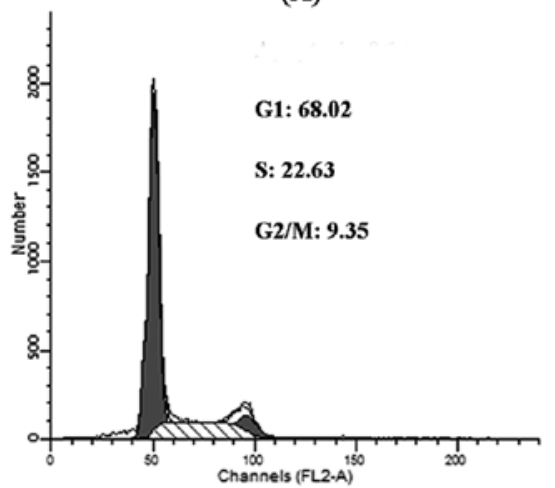

(C)

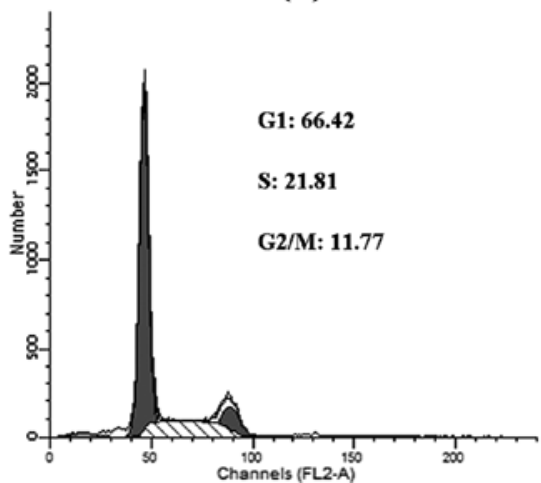

(B)

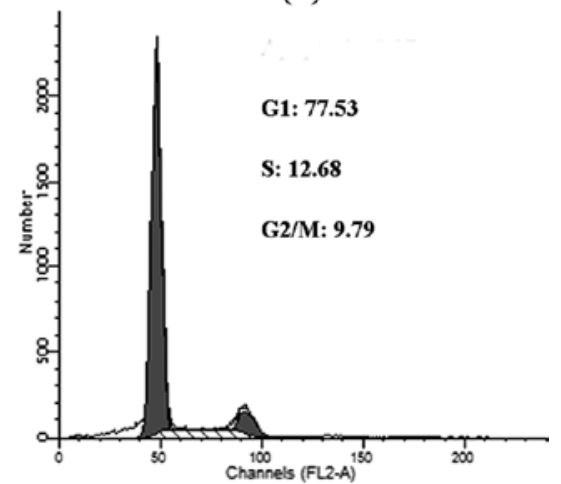

(D)

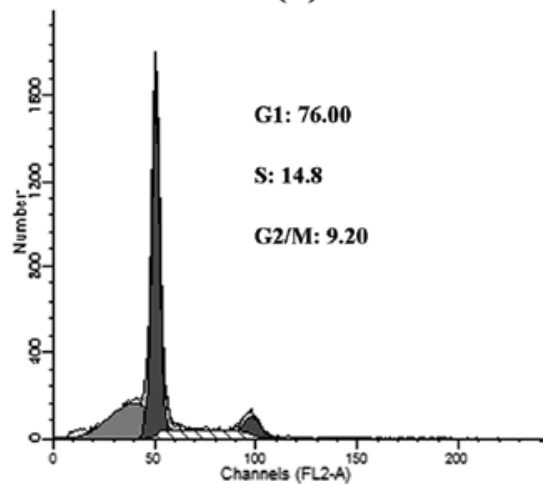

Figure 7. Effect of compound 6 on the cell cycle distribution of HeLa cells. HeLa cells were treated with either vehicle alone for 24 (A) and $48 \mathrm{~h}(\mathrm{C})$ or $150 \mu \mathrm{M}$ of compound 6 for 24 (B) and $48 \mathrm{~h}$ (D). Cell cycle distribution was calculated as the percentage of cells in the G1, S and G2/M phase. The data are of three independent experiments. 


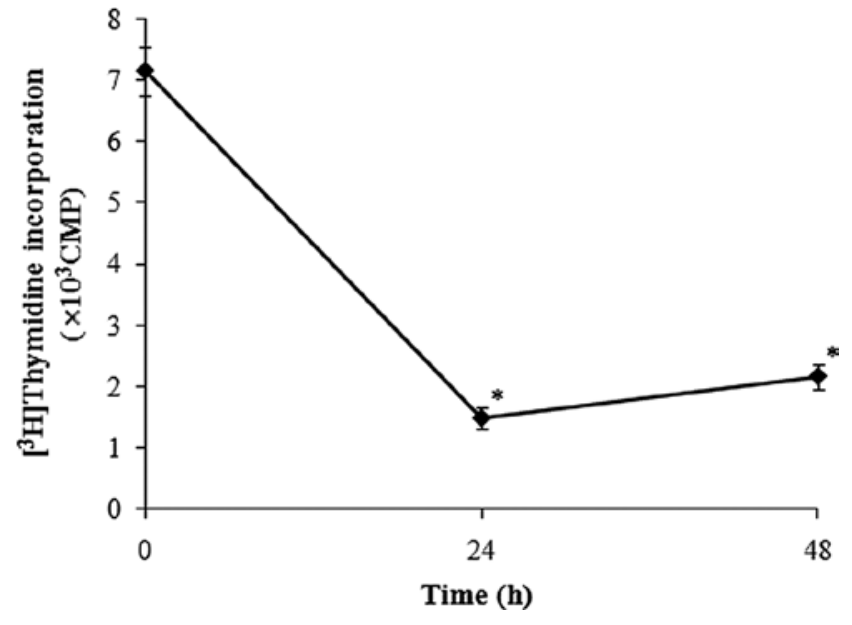

Figure 8. Inhibitory effect of compound 6 on $\left[{ }^{3} \mathrm{H}\right] \mathrm{dTTP}$ incorporation of HeLa cells. Results are the mean $\pm \mathrm{SD}, \mathrm{n}=3{ }^{*} \mathrm{P}<0.05$, means significantly differ from the control at the same level.

transition from the $\mathrm{G} 1$ to the $\mathrm{S}$ phase of cell cycle, suggesting that the observed apoptosis induced by compound 6 might be due to an arrest of DNA synthesis, thereby, inhibiting further progress in the cell cycle.

Compound 6 induces DNA damage. To directly determine if compound 6 induces DNA damage, we performed an alkaline comet assay, a sensitive method that detects DNA single- and double-strand breaks, alkali-labile sites, and incomplete excision repair sites at the single-cell level based on the increased tail of DNA migration (33). Fig. 9A shows the DNA migration patterns in HeLa cells. When cells were treated with compound 6 for $24 \mathrm{~h}$, DNA damage, as indicated by the increased olive tail moment (OTM) (Fig. 9B), started to be evident corresponding to the increased tails of DNA migration (Fig. 9A). After a $48 \mathrm{~h}$ treatment, almost the entire population of $\mathrm{HeLa}$ cells contained damaged DNA.

\section{Discussion}

In this study, the cytotoxic activity of seven cromakalim analogues against HeLa cells was evaluated. Compounds 4, 6 and 7 showed significant cytotoxicity against HeLa cells compared with the control, while no expressive effect was observed for any of the other cromakalim analogues. According to the chemical structure of these compounds, the nature of the substituent in the 6 position appeared to be important for the cytotoxic effect on HeLa cells. Indeed, compounds that had a phenyl group in this position demonstrated a cytotoxic effect on HeLa cells. Moreover, the presence in the 6 position of phenylurea further enhanced their cytotoxicity (compound 6 and 7). The $\mathrm{IC}_{50}$ value of compound 7 was closer to its enantiomer, compound 6(Table I), indicating that the stereochemical structure is not crucial to the cytotoxic effect on HeLa cells. Among the tested cromakalim analogues, compound 6 exhibited the highest cytotoxicity on HeLa cells $\left(\mathrm{IC}_{50}\right.$ of $\left.138 \mu \mathrm{M}\right)$ and inhibited the cell proliferation significantly after $36 \mathrm{~h}$ incubation.
(A)

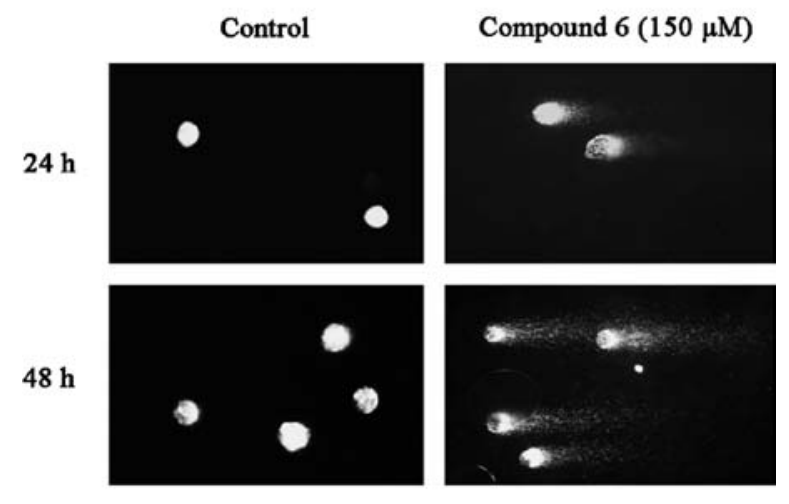

(B)

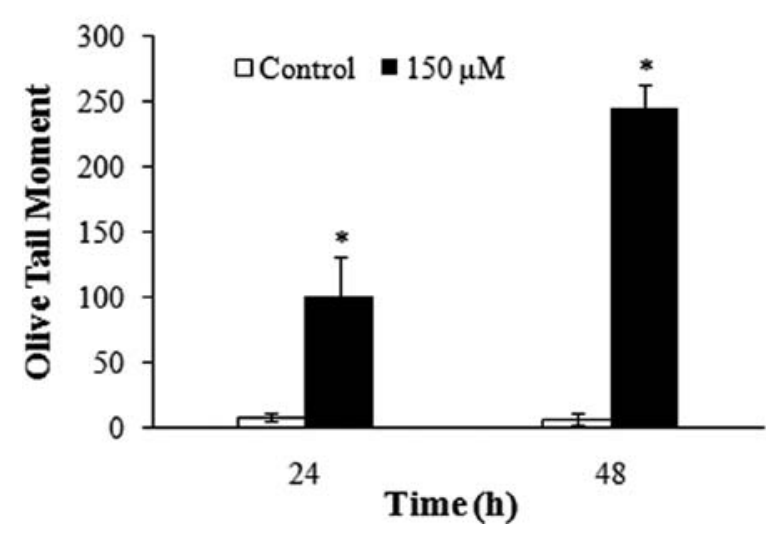

Figure 9. Compound 6 induces DNA-strand breaks in HeLa cells. (A) DNA single-strand breaks induced by compound 6 in HeLa cells. (B) Olive tail moment of DNA from HeLa cells treated with $150 \mu \mathrm{M}$ of compound 6. Results are the mean $\pm \mathrm{SD}, \mathrm{n}=3$. ${ }^{*} \mathrm{P}<0.05$, means significantly differ from the control at the same level.

To obtain a better insight into the mechanism of cytotoxicity induced by compound 6, its effect on apoptosis was evaluated. Marked morphological changes indicative of cell apoptosis were clearly observed, and the result of the Annexin V-FITC/PI double staining assay indicated that compound 6 induced early apoptosis in HeLa cells at $48 \mathrm{~h}$. Based on these findings, Western blot analysis was performed to further investigate the potential apoptotic pathway in HeLa cells treated by compound 6 . The Bcl-2 family proteins Bax and Bcl-2 play important roles in initiating the mitochondriamediated apoptotic pathway (19). Pro-apoptotic protein Bax translocates to the mitochondria and integrates into the outer mitochondrial membrane, where it promotes the release of cytochrome c into the cytosol. In contrast, anti-apoptotic protein $\mathrm{Bcl}-2$ prevents this process by preserving mitochondrial integrity. Thus, the ratio of Bax to $\mathrm{Bcl}-2$ is crucial to the sustenance of drug-induced apoptosis in the mitochondriamediated apoptotic pathway (34). The present study showed that compound 6 upregulated the expression level of Bax and downregulated the expression level of Bcl-2, eventually leading to an increase in the ratio of $\mathrm{Bax} / \mathrm{Bcl}-2$ protein levels. The release of mitochondrial cytochrome $\mathrm{c}$ facilitates the formation of apoptosome complex consisting of Apaf-1 and caspase-9, which subsequently activates effector caspases such 
as caspase-3 and leads to apoptosis (15). In the present study, the release of cytochrome $\mathrm{c}$ and the activation of caspase- 9 and -3 were detected. These results suggest that compound 6 -induced apoptosis is via a caspase- and mitochondriadependent pathway.

Since the activation and execution of apoptosis are regulated by complex molecular mechanisms, numerous points of interaction between the regulatory pathway of the cell cycle and apoptosis exist (35). Our data clearly showed that the significant increase of G1 phase cells was accompanied by a decrease of S-phase cells. Thus, the blockage effect of compound 6 occurred at the G1/S transitions, and this effect is associated with the inhibition of DNA synthesis. Moreover, results from the comet assay showed that $\sim 70 \%$ of the cell population contained DNA-strand breaks after only $24 \mathrm{~h}$ of incubation with compound 6. Collin et al and Speit et al comment that the single-strand breaks observed in the alkaline version are not the most noteworthy of DNA lesions because they may be rapidly repaired and not regarded as a significantly lethal or mutagenic lesion $(36,37)$. However, through the process of apoptosis any cell which is severely damaged beyond the capacity of the DNA repair system is to be eliminated. It is of note to find that compound 6 induced significant DNA damage and cell cycle arrest after only 24 $\mathrm{h}$ treatment, when the apoptosis was barely detectable. What is more, after a 48 -h treatment, almost the entire population of HeLa cells contained damaged DNA, while the early apoptotic cells increased by only $15 \%$ compared with the control. Therefore, we conclude that compound 6 induces DNA-strand break and cell cycle arrest before early apoptosis has occurred. It is thus suggested that compound 6 causes DNA damage leading to G1 cell cycle arrest for prevention of DNA synthesis to buy time for DNA repair; however, since the DNA damage caused by compound 6 is too severe to be repaired, HeLa cells undergo apoptosis via caspase- and mitochondria-dependent pathway.

In conclusion, our study provides experimental evidence that compound 6 induces HeLa cell apoptosis via the mitochondria-mediated and caspase-dependent pathway. Compound 6 also induces DNA damage and G1 cell cycle arrest to inhibit DNA replication. Collectively, these findings provide important clues for further evaluating the potential potency of cromakalim analogues for use in cancer therapy.

\section{Acknowledgements}

This work was supported by the 2010 Inje University research grant.

\section{References}

1. Lee YS, Sayeed MM and Wurster D: In vitro antitumor activity of cromakalim in human brain tumor cells. Pharmacology 49: 69-74, 1994.

2. Caliendo G, Grieco P, Perissutti E, et al: Synthesis, biological activity and conformational study of 1,4-benzoxazine derivatives as potassium channel modulators. Eur J Med Chem 33: 957-967, 1998.

3. Sebille S, de Tullio P, Becker B, et al: 4,6-Disubstituted 2,2-dimethylchromans structurally related to the KATP channel opener cromakalim: design, synthesis, and effect on insulin release and vascular tone. J Med Chem 48: 614-621, 2004.
4. Bergmann R and Gericke R: Synthesis and antihypertensive activity of 4-(1,2-dihydro-2-oxo-1-pyridyl)-2H-1-benzopyrans and related compounds, new potassium channel activators. J Med Chem 33: 492-504, 1990.

5. Yoo SE, Yi KY, Lee S, et al: A novel anti-ischemic ATP-sensitive potassium channel (KATP) opener without vasorelaxation: $\mathrm{N}-(6-$ aminobenzopyranyl)-N'-benzyl-N"'-cyanoguanidine analogue. J Med Chem 44: 4207-4215, 2001.

6. Han Z, Wei W, Dunaway S, et al: Role of p21 in apoptosis and senescence of human colon cancer cells treated with camptothecin. J Biol Chem 277: 17154-17160, 2002.

7. Kowalska-Loth B, Girstun A, Piekiełko A and Staroń K: SF2/ ASF protein inhibits camptothecin-induced DNA cleavage by human topoisomerase I. Eur J Biochem 269: 3504-3510, 2002.

8. Singh NP, McCoy MT, Tice RR and Schneider EL: A simple technique for quantitation of low levels of DNA damage in individual cells. Exp Cell Res 175: 184-191, 1988.

9. Gasser S: DNA damage response and development of targeted cancer treatments. Ann Med 39: 457-464, 2007.

10. Hengartner MO: The biochemistry of apoptosis. Nature 407: 770-776, 2000.

11. Brown JM and Wouters BG: Apoptosis, p53, and tumor cell sensitivity to anticancer agents. Cancer Res 59: 1391-1399, 1999.

12. Earnshaw WC: Nuclear changes in apoptosis. Curr Opin Cell Biol 7: 337-343, 1995.

13. Reed JC and Green DR: Remodeling for demolition: changes in mitochrondrial ultrastructure during apoptosis. Mol Cell 9: 1-3, 2002.

14. Wang $\mathrm{C}$ and Youle RJ: The role of mitochondria in apoptosis*. Ann Rev Genet 43: 95-118, 2009.

15. Ghobrial IM, Witzig TE and Adjei AA: Targeting apoptosis pathways in cancer therapy. CA Cancer J Clin 55: 178-194, 2005.

16. Gupta S: Molecular signaling in death receptor and mitochondrial pathways of apoptosis. Int J Oncol 22: 15-20, 2003.

17. Marzo I, Brenner C, Zamzami N, et al: The permeability transition pore complex: a target for apoptosis regulation by caspases and Bcl-2-related proteins. J Exp Med 187: 1261-1271, 1998.

18. Kuwana T and Newmeyer DD: Bcl-2-family proteins and the role of mitochondria in apoptosis. Curr Opin Cell Biol 15: 691-699, 2003.

19. Gross A, McDonnell JM and Korsmeyer SJ: BCL-2 family members and the mitochondria in apoptosis. Genes Dev 13: 1899-1911, 1999.

20. Tominaga $\mathrm{H}$, Ishiyama $\mathrm{M}$, Ohseto $\mathrm{F}$, et al: A water-soluble tetrazolium salt useful for colorimetric cell viability assay. Anal Comm 36: 47-50, 1999.

21. Qi F, Li A, Zhao L, et al: Cinobufacini, an aqueous extract from Bufo bufo gargarizans Cantor, induces apoptosis through a mitochondria-mediated pathway in human hepatocellular carcinoma cells. J Ethnopharmacol 128: 654-661, 2010.

22. Zhang Y AE, Jiang Y, Kim DK, Kang SG, Wu C, Kang SW, Park JS, Son BW and Jung JH: 3-Chloro-2,5-dihydroxybenzyl alcohol activates human cervical carcinoma HeLa cell apoptosis by inducing DNA damage. Int J Oncol 31: 1317-1323, 2007.

23. Lin SY, Liu JD, Chang HC, Yeh SD, Lin CH and Lee WS: Magnolol suppresses proliferation of cultured human colon and liver cancer cells by inhibiting DNA synthesis and activating apoptosis. J Cell Biochem 84: 532-544, 2002.

24. Miao C DJ, Dang HT, Jeong IH, You S, Park JS, Jung JH, Kim DK: Apoptotic activity of fatty acid derivatives may correlate with their inhibition of DNA replication. Int $\mathrm{J}$ Oncol 33: 1291-1298, 2008.

25. Hellman B, Vaghef $H$ and Boström B: The concepts of tail moment and tail inertia in the single cell gel electrophoresis assay. Mutat Res/DNA Repair 336: 123-131, 1995.

26. Rojas E, Lopez MC and Valverde M: Single cell gel electrophoresis assay: methodology and applications. J Chromatogr B Biomed Sci Appl 722: 225-254, 1999.

27. Ashby J, Tinwell H, Lefevre PA and Browne MA: The single cell gel electrophoresis assay for induced DNA damage (comet assay): measurement of tail length and moment. Mutagenesis 10: 85-90, 1995.

28. Vermes I, Haanen C, Steffens-Nakken H and Reutellingsperger C: A novel assay for apoptosis flow cytometric detection of phosphatidylserine expression on early apoptotic cells using fluorescein labelled Annexin V. J Immunol Methods 184: 39-51, 1995.

29. Del Bino G, Darzynkiewicz Z, Degraef C, Mosselmans R, Fokan D and Galand P: Comparison of methods based on annexin-V binding, DNA content or TUNEL for evaluating cell death in HL-60 and adherent MCF-7 cells. Cell Prolif 32: 25-37, 1999. 
30. Sánchez I and Dynlacht BD: New insights into cyclins, CDKs, and cell cycle control. Semin Cell Dev Biol 16: 311-321, 2005.

31. Lee S, Christakos S and Small MB: Apoptosis and signal transduction: clues to a molecular mechanism. Curr Opin Cell Biol 5: 286-291, 1993

32. Smith DM GG, Zhang X, Wang G and Dou QP: Regulation of tumor cell apoptotic sensitivity during the cell cycle. Int $\mathrm{J}$ Mol Med 6: 503-510, 2000.

33. Hartmann A, Agurell E, Beevers C, et al: Recommendations for conducting the in vivo alkaline Comet assay. Mutagenesis 18: $45-51,2003$.
34. Qi F, Inagaki Y, Gao B, et al: Bufalin and cinobufagin induce apoptosis of human hepatocellular carcinoma cells via Fas- and mitochondria-mediated pathways. Cancer Sci 102: 951-958, 2011.

35. Evan GI and Vousden KH: Proliferation, cell cycle and apoptosis in cancer. Nature 411: 342-348, 2001.

36. Collins AR, Dobson VL, Duinská M, Kennedy G and Stětina R: The comet assay: what can it really tell us? Mutat Res/Fund Mol Mech Mut 375: 183-193, 1997.

37. Speit G, Dennog C and Lampl L: Biological significance of DNA damage induced by hyperbaric oxygen. Mutagenesis 13: 85-87, 1998. 